\title{
Struktur Komunitas dan Estimasi Karbon Sedimen Mangrove di Desa Sebubus Kabupaten Sambas Kalimantan Barat
}

\author{
Vivin Meidiana $^{1 *}$, Apriansyah ${ }^{1}$, Ika Safitri ${ }^{1}$ \\ 1 Program studi Ilmu Kelautan, FMIPA, Universitas Tanjunpura, Pontianak- \\ Indonesia \\ *Correspondence email: Vivin Meidiana \\ $\square$ vivinsupm@gmail.com
}

\section{Received:26 September 2019- Accepted: 2 October 2019 \\ Published: 31 October 2019 (C) Author(s) 2019. This article is open access}

\begin{abstract}
Ekosistem mangrove merupakan salah satu ekosistem pesisir perairan tropis yang memiliki tingkat produktivitas primer yang tinggi dan memiliki manfaat serta peranan penting bagi organisme akuatik juga bagi kepentingan manusia. Salah satu peran penting hutan mangrove sebagai penyerap dan penyimpan karbon dalam upaya penanggulangan pemanasan global. Desa Sebubus Kabupaten Sambas Kalimantan Barat memiliki kawasan ekosistem mangrove yang belum diketahui secara pasti struktur komunitas dan estimasi kandungan karbon organik. Oleh karena itu, penelitian mengenai struktur komunitas dan estimasi karbon organik hutan mangrove perlu dilakukan. Penelitian ini dilakukan pada bulan Januari dan Februari 2019. Metode pengambilan data komunitas mangrove dan sampel sedimen yaitu dengan menggunakan transek lingkaran. Analisis data komunitas mangrove menggunakan indeks Shannon-Winner sedangkan analisis karbon organik menggunakan Loss on ignition (LOI). Hasil penelitian menunjukan bahwa keanekagaraman jenis mangrove di Desa Sebubus Kabupaten Sambas tergolong rendah berkisar antara 0-0,9865 ind/Ha dan diperoleh 5 jenis mangrove yaitu Excocaria agallocha, Ceriops tagal, Soneratia alba, Bruguiera gymnoryza dan Rhizophora mucronata. Kandungan karbon organik berdasarkan variasi kedalaman berkisar antara 2,5-12,43 $\mathrm{Mg} / \mathrm{ha}^{-1}$. Dimana karbon tertinggi pada kedalaman 0-60 cm.
\end{abstract}

Keywords: Makrozoobentos, Mangrove, Kabupaten Mempawah, Keanekaragaman

\section{Pendahuluan}

Ekosistem mangrove merupakan salah satu ekosistem pesisir perairan tropis yang memiliki tingkat produktivitas primer tinggi (Mukherjee et al., 2014) mencapai 2.700 gr $\mathrm{C} / \mathrm{m}^{2} /$ tahun (Supriharyono, 2017). Hutan mangrove memiliki manfaat dan peranan penting bagi organisme akuatik sebagai habitat, feeding ground, spawning ground, dan nursery ground berbagai jenis biota (Rangkuti et al., 2017), dan juga menyediakan layanan untuk kepentingan manusia (Kusen et al., 2016).

Fungsi ekologi hutan mangrove yaitu sebagai penyerap dan penyimpan karbon dalam upaya penanggulangan pemanasan 
global (Sondak, 2015). Hutan mangrove memiliki kemampuan menyerap karbon tiga kali lebih besar dibandingkan rata-rata penyimpanan karbon per hektar oleh hutan tropis daratan sebesar $1.023 \mathrm{Mg} \mathrm{C} / \mathrm{ha}$. (Donato et al., 2011). Penelitian terdahulu menyebutkan bahwa mangrove efektif menyerap karbon sekitar 70-80 \% yang tersimpan di dalam tanah sebagai bahan organik (Murdiyarso et al., 2014) Oleh karena itu, kawasan hutan mangrove memiliki peran potensial bagi persediaan karbon global (Alongi, 2008).

Mangrove dapat menanggulangi perubahan iklim dan berperan sebagai parameter blue carbon dengan mengikat $\mathrm{CO} 2$ dari atmosfer untuk proses fotosintesis dan mengubahnya menjadi karbon organik (Barbier et al., 2011) kemudian menyimpan (sequestration) dalam bentuk biomassa dan juga di dalam sedimen (Ati et al., 2014). Sedimen hutan mangrove memiliki jumlah simpanan karbon tertinggi (Kauffman et al., 2012) karena serasah yang jatuh akan didekomposisi oleh mikroorganisme dan menjadi salah satu sumber bahan organik pada sedimen mangrove (Susiana, 2011). Hutan mangrove memiliki peran penting dalam menyerap dan menyimpan karbon, serta penanggulangan pemanasan global. Oleh karena itu, penelitian mengenai struktur komunitas hutan mangrove di Desa Sebubus, Kabupaten Sambas, Kalimantan Barat penting untuk dilakukan kaitannya dengan estimasi kandungan karbon yang dapat diserap oleh mangrove sehingga dapat menunjang kegiatan pengelolaan kawasan secara berkelanjutan.

\section{Metode}

\subsection{Waktu dan tempat}

Penelitian dilakukan di kawasan ekosistem mangrove Desa Sebubus Kanupaten Sambas (Gambar 1) pada bulan Februari dan Maret 2019. Penentuan lokasi pengamatan mangrove menggunakan Purposive Sampling. Stasiun pengamatan dibagi menjadi 4 stasiun berdasarkan perbedaan aktivitas lingkungan. Stasiun I mewakili area dekat pemukiman, stasiun II mewakili area wisata mangrove, stasiun III mewakili area persawahan dan stasiun IV merupakan area yang kurang aktivitas manusia. Transek dibuat pada setiap stasiun yang ditarik secara tegak lurus dari awal ditemukanannya mangrove ke arah daratan (Gambar 2).

\subsection{Pengambilan sampel}

Pengambilan data struktur komunitas hutan mangrove dilakukan dengan menggunakan metode transek garis sepanjang $200 \mathrm{~m}$ diukur dari bibir sungai tegak lurus ke arah darat. Masing-masing stasiun pengamatan dibagi manjadi 2 plot berbentuk lingkaran dengan jarak antar plot adalah $50 \mathrm{~m}$. Ukuran plot pengamatan yaitu $\mathrm{r}=11,29 \mathrm{~m}$ untuk pengamatan kriteria mangrove tingkat pohon, $\mathrm{r}=5,64 \mathrm{~m}$ untuk pengamatan kriteria mangrove tingkat tiang, $\mathrm{r}=2,82 \mathrm{~m}$ untuk pengamatan kriteria mangrove tingkat pancang, dan $\mathrm{r}=1,13 \mathrm{~m}$ untuk pengamatan kriteria mangrove tingkat semai. Pada setiap plot pengamatan dilakukan perhitungan jumlah individu. Menurut Kepmen Lingkungan Hidup Nomor 201 Tahun 2001 pengukuran diameter batang pohon setinggi dada $(\mathrm{DBH}=$ Diameter Breast High) atau sekitar 1,3 m dari permukaan tanah.

Pengambilan sampel sedimen mangrove dilakukan dengan tahapan sebagai berikut :

1. Bersihkan serasah mangrove dari permukaan tanah

2. Kemudian Sedimen core dimasukkan ke dalam tanah secara vertikal di lokasi yang sudah ditentukan sampai kedalaman mencapai pangkal corer. Ketika corer telah mencapai kedalaman yang telah ditentukan kemudian tarik perlahan corer dari dalam tanah sambil terus diputar untuk mempertahankan agar sampel sedimen yang diambil tetap penuh dan lengkap

3. Sampel sedimen yang lengkap dan utuh kemudian dibagi berdasarkan 4 kedalaman (4 sampel), yaitu $0-30 \mathrm{~cm}$, $30-60 \mathrm{~cm}, 60-100 \mathrm{~cm}$, dan $>100 \mathrm{~cm}$. Pada kedalaman $0-30 \mathrm{~cm}$ hanya diambil pada kedalaman 10-20 cm, kedalaman 30-60 $\mathrm{cm}$ hanya sampel pada kedalaman 40-50 $\mathrm{cm}$, kedalaman 60-100 hanya sampel pada kedalaman 70-90 cm, dan pada kedalaman $>100 \mathrm{~cm}$ sampel hanya diambil pada kedalaman 110-120 cm

4. Masukkan sub-sampel ke dalam zipper bag dan berikan label pada setiap kantong untuk memudahkan identifikasi dan analisis di laboratorium

5. Masukkan sampel ke dalam cool box atau tempat khusus untuk dibawa ke laboratorium.

\subsection{Analisis Data}

Analisis ekosistem pesisir, seperti ekosistem mangrove menggunakan Indeks 


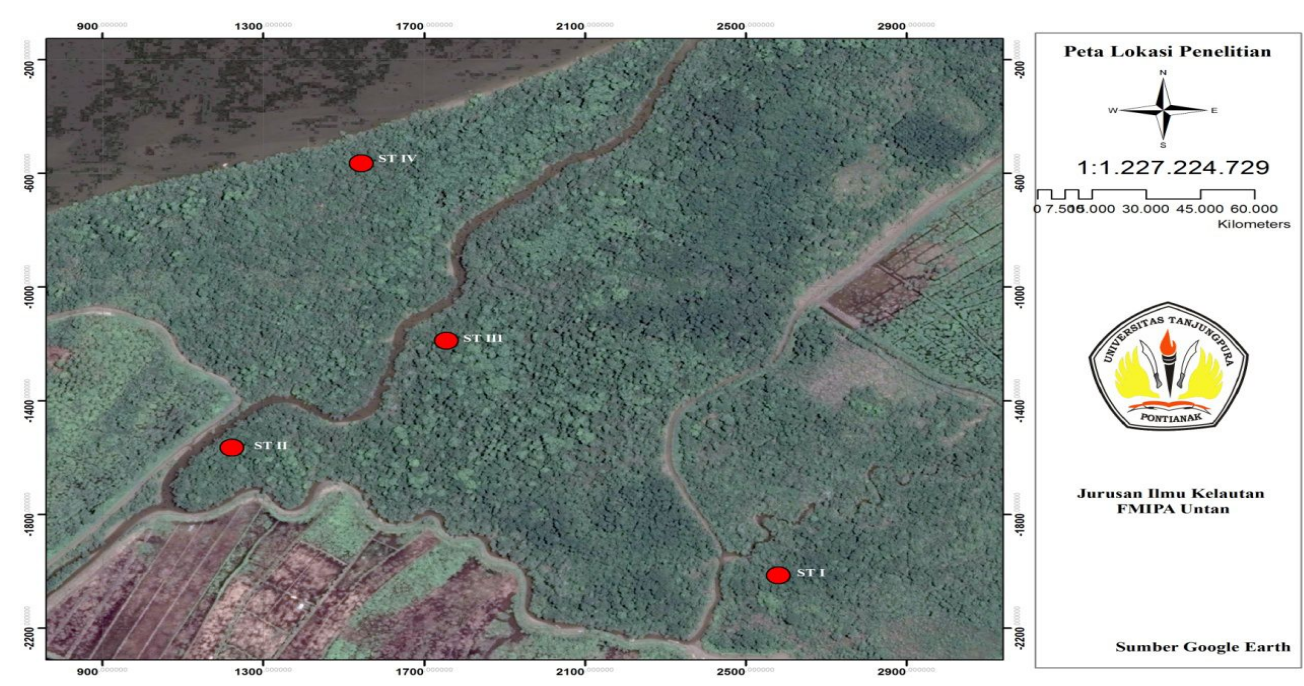

Gambar 1. Peta lokasi penelitian

\begin{tabular}{|c|c|}
\hline Dekat pemukiman & $\mathrm{N} 01^{\circ} 47.248^{\prime}-\mathrm{E} 109^{\circ} 19.899^{\prime}$ \\
\hline Area wisata mangrove & N 01⒋513'- E109¹9.909' \\
\hline Dekat persawahan & $\mathrm{N} \mathrm{01}^{\circ} 47.509^{\prime}-\mathrm{E} 109^{\circ} 19.892^{\prime}$ \\
\hline Jauh dari aktivitas manusia & $\mathrm{N} \mathrm{01}{ }^{\circ} 47.510^{\prime}-\mathrm{E} 109^{\circ} 19.891^{\prime}$ \\
\hline
\end{tabular}

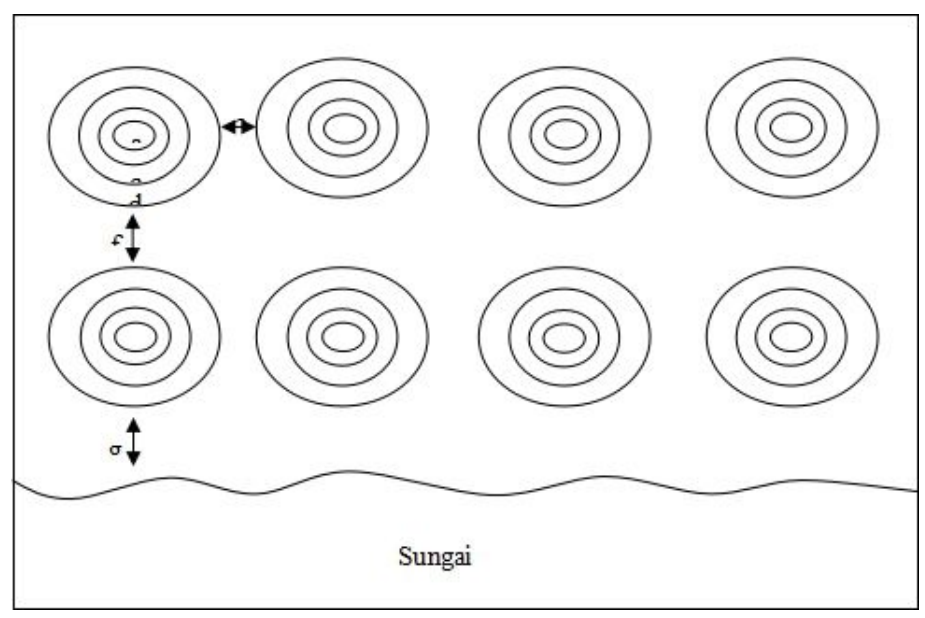

Gambar 2. Transek pengambilan sampel

Shannon-Wiener. Kondisi ekosistem mangrove digambarkan dengan kondisi keanekaragaman jenis, kerapatan jenis (K), kerapatan relatif jenis (KR), frekuensi jenis (F), frekuensi relatif jenis (FR), dominansi jenis (D), dominansi relatif (DR) dan nilai penting (NP) mangrove yang ada di stasiun pengamatan, sebagai berikut:

$$
\begin{aligned}
& K=\frac{\sum I S P}{L p} \\
& K R=\frac{K_{s j}}{K_{s s}} \times 100 \%
\end{aligned}
$$$$
\begin{aligned}
& F=\frac{\sum I S P}{\sum T_{j p}} \\
& K R=\frac{f_{s j}}{f_{s s}} \times 100 \% \\
& D=\frac{L_{B}}{L_{P}} \\
& D R=\frac{D_{s}}{D_{s s}} \times 100 \% \\
& I N P=K R+F R+D R
\end{aligned}
$$

Keterangan : 
$I S P=$ Individu suatu spesies

$L_{p}=$ Luas petak contoh

$K_{s j}=$ Kerapatan suatu jenis

$K_{s s}=$ Kerapatan seluruh spesies

$T_{j p}=$ Total jenis pada plot

$f_{s j}=$ Frekuensi suatu jenis

$f_{s s}=$ Frekuensi seluruh spesies

$L_{B}=$ Luas bidang dasar suatu spesies

$L_{p}=$ Luas petak contoh

$D_{s}=$ Dominasi suatu spesies

$D_{s s}=$ Dominasi seluruh spesies

Data yang ukur dalam menentukan estimasi karbon organik adalah kedalaman sampel sedimen, densitas tanah, densitas karbon, estimasi karbon dan persentase karbon organik pada sedimen. Adapun perhitungan yang digunakan dalam menganalisis data sebagai berikut (Howard et al., 2014):

$$
\begin{aligned}
& B D=\frac{m_{b k}}{V_{s}} \\
& \% B O=\frac{W_{o}-W_{t}}{W_{o}} \times 100 \% \\
& \% C=(1 / 1.724) \times \% B O
\end{aligned}
$$

Soil C density $\left(\mathrm{g} \mathrm{cm}^{-3}\right)=\% \mathrm{Cx}$ BD

Soil C $\left(\mathrm{Mg} \mathrm{ha}^{-1}\right) \quad=$ BDxSDIx $\% \mathrm{C}$

\section{Hasil dan Pembahasan}

Proses Hasil pengamatan dan identifikasi berdasarkan ciri morfologi mangrove diperoleh sebanyak 5 spesies yaitu Excocaria agallocha, Ceriops tagal, Soneratia alba, Bruguiera gymnoryza dan Rhizophora mucronata. Penelitian serupa di desa Sebubus, pada titik lokasi pengamatan yang berbeda juga menemukan jenis mangrove diantaranya $A$. marina, B. cylindrica, $B$. gymnorhiza, E. agallocha, R. mucronata, $R$. stylosa dan S. alba (Hambran, 2014; Habdiansyah, 2015). Tegakan mangrove berkaitan erat dengan penguasaan tempat tumbuh yang dipengaruhi oleh besarnya pasokan cahaya matahari, ketersediaan air tanah dan unsur hara bagi pertumbuhan jenis mangrove (Setiawan dan Mursidin, 2018).

Pada lokasi penelitian, persentase tertinggi jenis mangrove tingkat pohon adalah $S$. alba $(28,89 \%)$ dan persentase terendah adalah $E$. agallocha (11,11\%) (Gambar 3). S.alba ditemukan di stasiun II dan III plot 1 dan 2, serta stasiun IV plot 2. Banyaknya $S$. alba pada tingkatan pohon dikarenakan bahwa jenis ini tidak banyak dimanfaatkan oleh manusia. Sedangkan jenis R. mucronata yang memiliki bentuk batang lurus dan tidak berbuku banyak dimanfaatkan sebagai bahan bangunan, kayu bakar.

Komposisi jenis mangrove tingkat pancang (Gambar 4) yang banyak dijumpai adalah $R$. mucronata dengan persentase sebesar 29,03 \% dan tingkat persentase terendah adalah $S$. alba sebesar 9,68\%. R. mucronata pada tingkat pancang ditemukan di stasiun IV plot 1 dan 2. Stasiun IV merupakan stasiun pengamatan yang mewakili area jauh dari aktivitas manusia dengan kondisi lingkungan yang optimal untuk pertumbuhan mangrove, dimana salinitas tanah $25,20 \mathrm{ppt}$, suhu $28{ }^{0} \mathrm{C}, \mathrm{pH}$ tanah 6,50 dan oksigen terlarut $5,53 \mathrm{mg} / \mathrm{L}$ serta tekstur tanah lumpur lempung. Dominansi $R$. mucronata dikarenakan memiliki kemampuan tumbuh dan berkembangbiak dengan cepat (Tefarani et

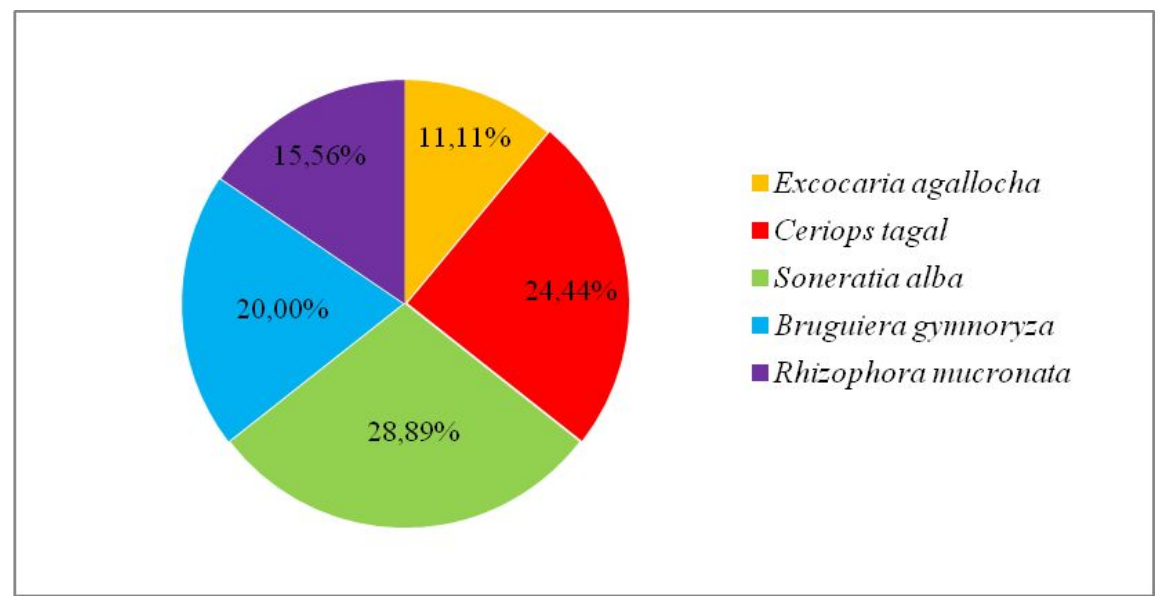

Gambar 3. Komposisi mangrove tingkat pohon 


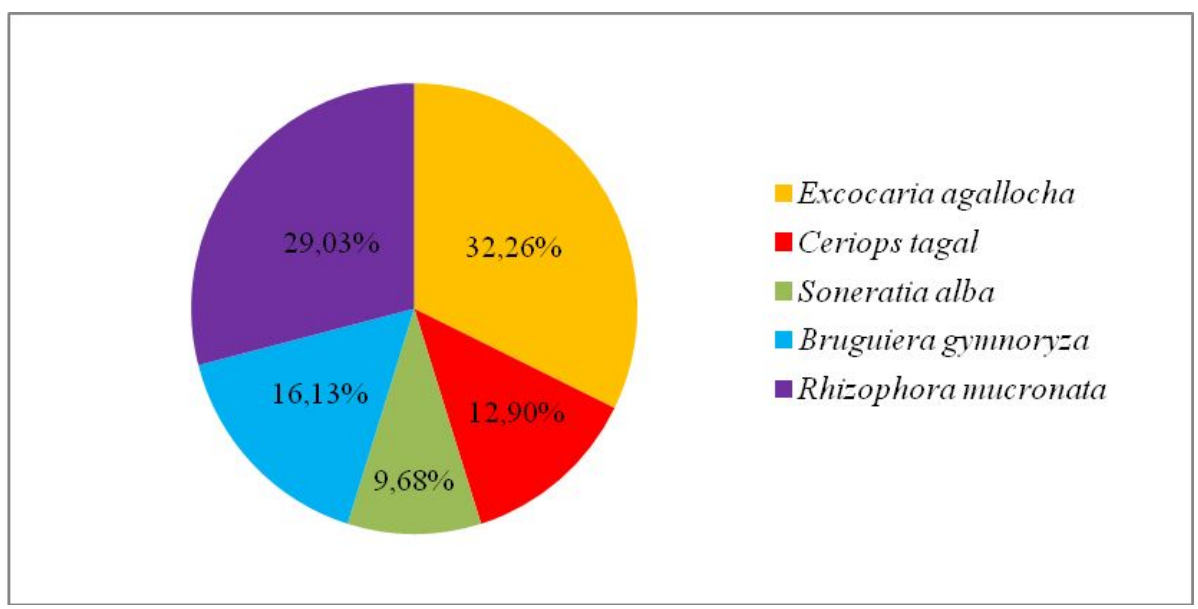

Gambar 4. Komposisi mangrove tingkat tiang

al., 2019), serta mendominasi pada substrat yang berlumpur (Tolangara dan Ahmad, 2017).

Mangrove tingkat pancang jenis $R$. mucronata dijumpai pada stasiun III dan IV pada plot 1 dan 2 dengan nilai persentase tertinggi $54,55 \%$. Sedangkan $C$. tagal dengan persentase terendah $(4,55 \%)$ ditemukan pada stasiun II plot 1. Pada tingkatan semai, hanya ditemukan satu jenis mangrove $R$. mucronata dengan nilai persentase $100 \%$ dan hanya ditemukan pada stasiun III plot 1. Rizhophora pada umumnya memiliki kemampuan adaptasi dan dapat tumbuh baik pada tanah berlumpur (Bengen, 2001; Winanrno et al., 2016; Tulenan et al., 2018). Selain itu, mangrove merupakan tumbuhan khas pantai daerah tropis yang hidup pada kisaran suhu $19-40{ }^{\circ} \mathrm{C}$ dengan toleransi fluktuasi suhu tidak lebih dari $10{ }^{\circ} \mathrm{C}$ (Darmadi, 2014).

\subsection{Kerapatan jenis mangrove}

Hasil penelitian tingkat kerapatan vegetasi mangrove di Desa Sebubus Kabupaten
Sambas dianalisis berdasarkan 4 titik lokasi pengamatan. Pada tingkat pohon, hasil yang didapat di 4 stasiun pengamatan ditemukan 5 jenis mangrove (Gambar 5).

Stasiun I untuk tingkat pohon hanya ditemukan mangrove E. agallocha sebesar 62,5 ind/Ha. Kerapatan tertinggi jenis $C$. tagal terdapat pada stasiun II (125 ind/Ha) dan terendah pada stasiun III sebesar 12,5 ind/Ha. Mangrove B. gyimnoryza ditemukan di stasiun III dengan nilai kerapatan tertinggi yaitu sebesar 87,5 ind/Ha dan kerapatan terendah pada stasiun IV sebesar 25 ind/Ha. Kerapatan jenis tertinggi untuk $\mathrm{S}$. alba ditemukan di stasiun III sebesar 112,5 ind/Ha dan terendah pada stasiun II $(12,5 \mathrm{ind} / \mathrm{Ha})$. Sedangkan mangrove $R$. mucronata hanya ditemukan di stasiun IV dengan nilai kerapatan tertinggi sebesar 87,5 ind/Ha. Berdasarkan Keputusan Menteri Negara Lingkungan Hidup No. 201 tahun 2004 mangrove tingkat pohon dikategorikan dalam kerapatan rendah. Mangrove E. agallocha pada stasiun I kawasan yang dekat dengan aktvitas manusia, memiliki nilai kerapatan

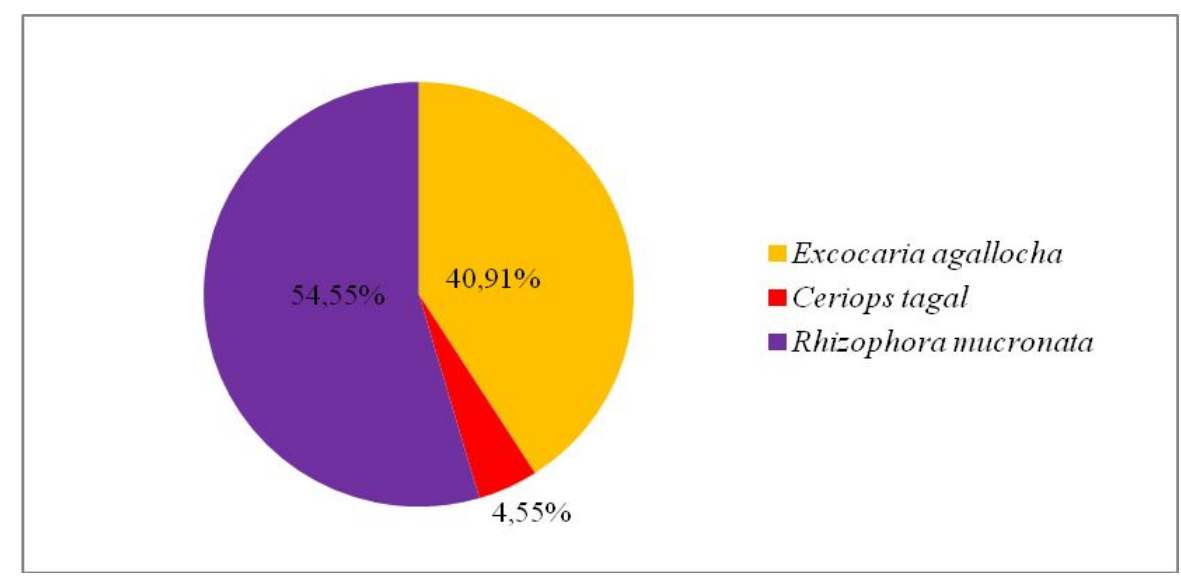

Gambar 5. Komposisi mangrove tingkat pancang 


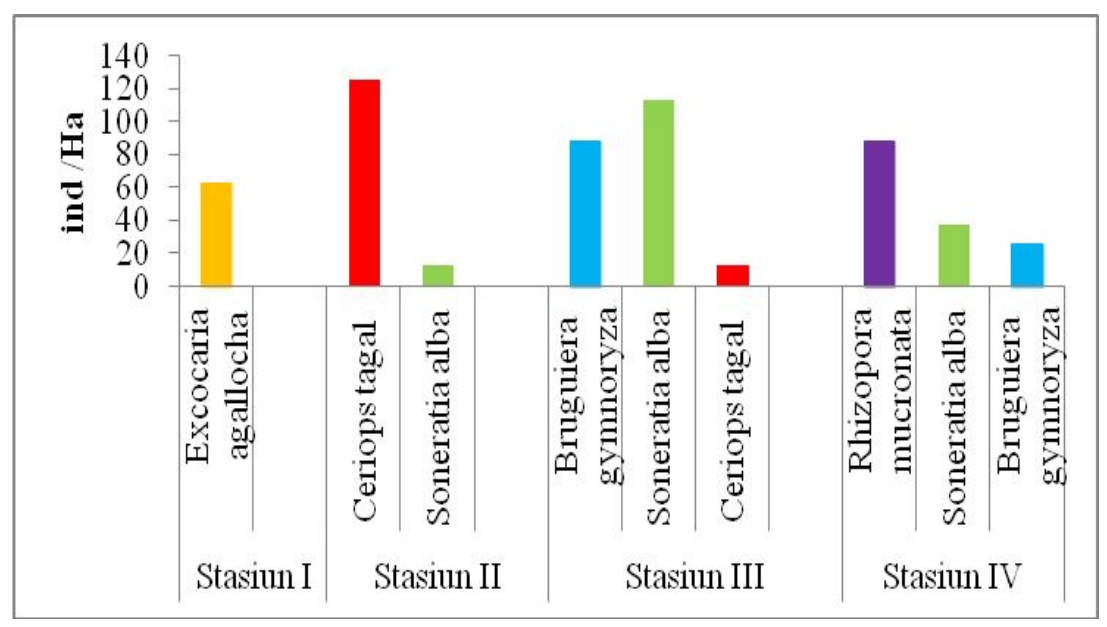

Gambar 6. Kerapatan jenis mangrove tingkat pohon

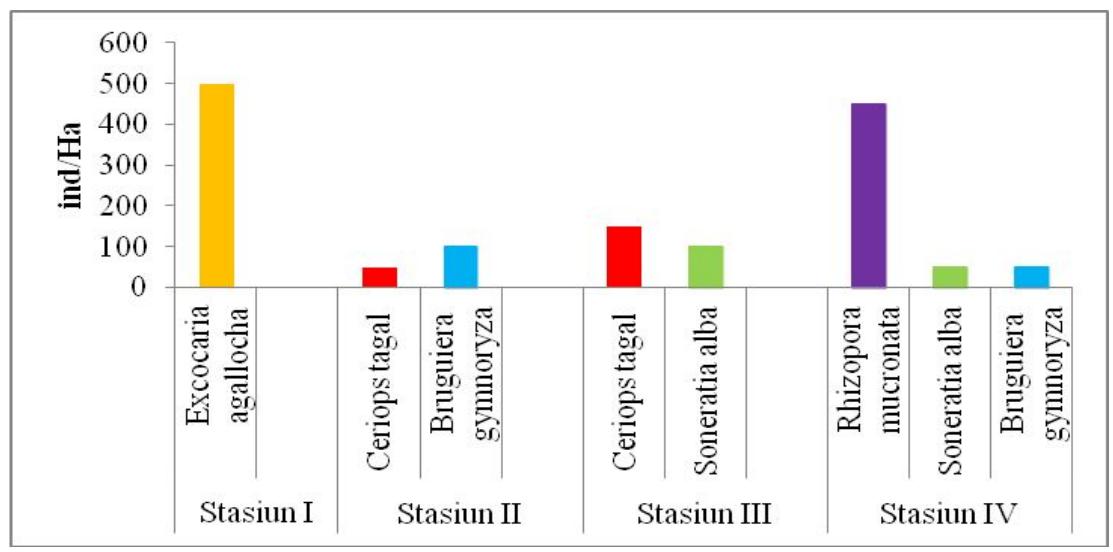

Gambar 7. Kerapatan jenis mangrove tingkat tiang

jenis dan relatif tertinggi dibandingkan jenis lainnya sehingga dapat dikatakan bahwa jenis ini mampu beradaptasi pada lingkungan yang dekat dengan aktivitas antropogenik.

Mangrove E. agallocha tingkat tiang hanya ditemukan pada stasiun I dengan kerapatan jenis sebesar $500 \mathrm{ind} / \mathrm{Ha}$ dan nilai kerapatan relatif 100\% (Gambar 6 dan 7). Kerapatan tertinggi jenis mangrove $C$. tagal terdapat pada stasiun III sebesar $150 \mathrm{ind} / \mathrm{Ha}$ dengan kerapatan relatif $60 \%$ dan terendah pada stasiun II (50 ind/Ha), kerapatan relatif sebesar $20 \%$. B. gymnoryza tingkat tiang dengan kerapatan tertinggi ditemukan pada stasiun II yaitu $100 \mathrm{ind} / \mathrm{Ha}$ (kerapatan $80 \%$ ) dan kerapatan jenis terendah (50 ind/Ha) pada stasiun IV dengan kerapatan relatif $9,09 \%$. Kerapatan jenis tertinggi mangrove $\mathrm{S}$. alba ditemukan pada stasiun III yaitu 200 ind/Ha, kerapatan relatif $40 \%$ dan terendah pada stasiun IV $(50 \mathrm{ind} / \mathrm{Ha})$ dengan kerapatan relatif 9,09\%. Sedangkan R. mucronata hanya ditemukan di stasiun IV dengan kerapatan jenis 450 ind/Ha dan kerapatan relatif $81,81 \%$.
Berdasarkan hasil pengamatan jenis mangrove tingkat tiang di Desa Sebubus Kabupaten Sambas menunjukan bahwa mangrove E. agallocha ditemukan dengan nilai kerapatan jenis dan kerapatan relatif tertinggi hal ini juga ditemukan pada mangrove tingkat pohon sehingga memperkuat pernyataan bahwa mangrove E. agallocha mampu beradaptasi pada lingkungan yang dekat dengan kawasan aktivitas manusia.

Mangrove tingkat pancang (Gambar 8), nilai kerapatan tertinggi di stasiun I yaitu $\mathrm{E}$. agallocha sebesar 1800 pancang/ha, berdasarkan Keputusan Menteri Negara Lingkungan Hidup No. 201 tahun 2004, kerapatan jenis mangrove E. agallocha di stasiun I tergolong rapat dimana nilai kerapatan lebih dari $\geq 1500$ ind $/ \mathrm{Ha}$ dan dengan kerapatan relatif $100 \%$. C. tagal sebesar $200 \mathrm{ind} / \mathrm{Ha}$ hanya ditemukan di stasiun II dengan kerapatan relatif $100 \%$, mangrove C.tagal tingkat tiang dinyatakan dalam kategori kerapatan yang sangat rendah. Sedangkan $R$. mucronata ditemukan pada stasiun IV dengan nilai kerapatan jenis 


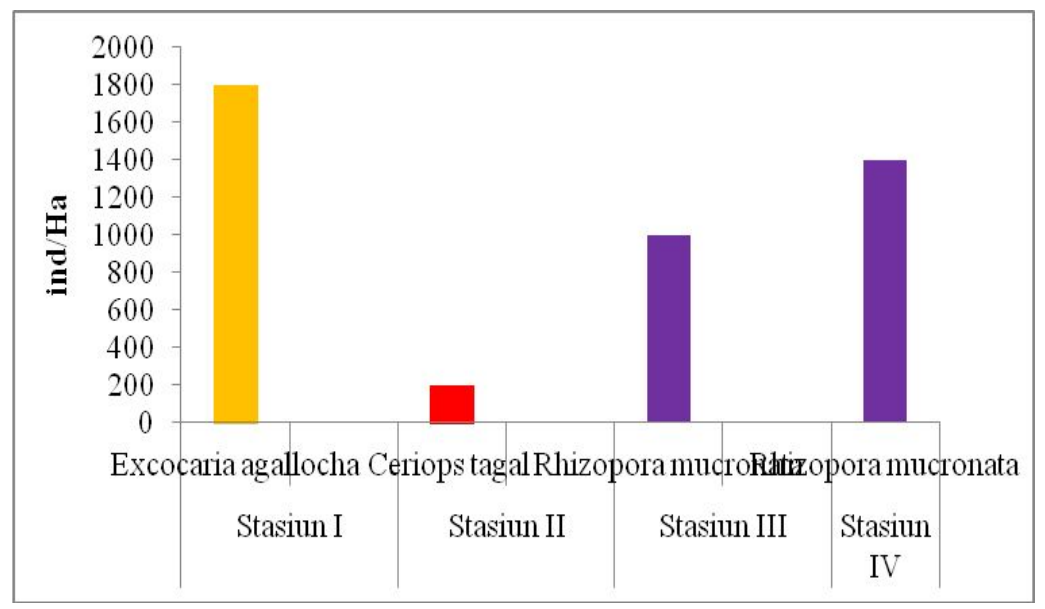

Gambar 8. Kerapatan jenis mangrove tingkat pancang

tertinggi sebesar $1400 \mathrm{ind} / \mathrm{Ha}$ dan terendah pada stasiun III (1000 ind/Ha), R. mucronata dikategorikan tingkat kerapatan sedang dengan kerapatan relatif $100 \%$.
Jenis mangrove untuk tingkatan semai hanya ditemukan pada stasiun III yaitu jenis R. mucronata dengan kerapatan relatif $100 \%$. Hal ini diduga karena nilai kerapatan pada tingkatan pohon, tiang dan pancang lebih tinggi apabila dibandingkan dengan jenis mangrove tingkatan semai yang dapat menyebabkan kurangnya pasokan cahaya matahari yang masuk ke dalam lahan

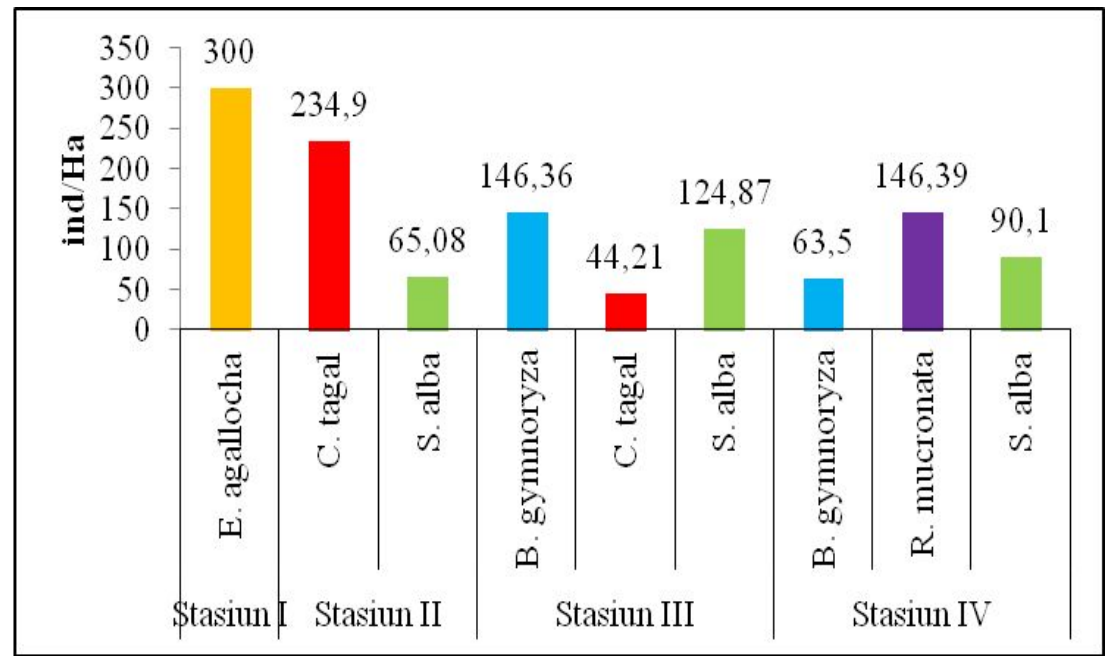

Gambar 9. Indeks Nilai Penting tingkat Pohon

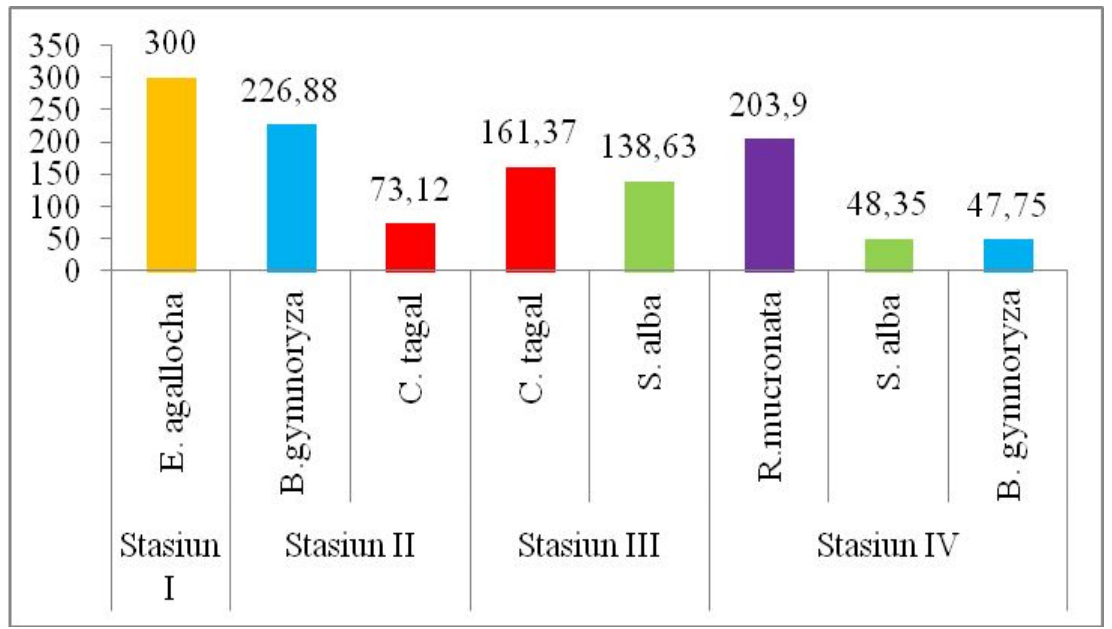

Gambar 10. Indeks Nilai Penting tingkat Tiang 
Tabel 1. Kenakekaragaman jenis mangrove di Desa Sebubus

\begin{tabular}{clcccc}
\hline \multirow{2}{*}{ Stasiun } & \multirow{2}{*}{ Area } & \multicolumn{4}{c}{ Keanekaragaman (H') } \\
\cline { 3 - 6 } & & Pohon & Tiang & Pancang & Semai \\
\hline I & Dekat pemukiman & 0 & 0 & 0 & 0 \\
II & Area wisata mangrove & $\mathbf{0 , 3 0 4 6}$ & $\mathbf{0 , 3 2 1 8}$ & 0 & 0 \\
III & Dekat persawahan & $\mathbf{0 , 8 6 8 7}$ & $\mathbf{0 , 6 7 3 0}$ & 0 & 0 \\
IV & Jauh dari aktivitas manusia & $\mathbf{0 , 9 5 9 6}$ & $\mathbf{0 , 6 0 0 1}$ & 0 & 0 \\
\hline
\end{tabular}

kawasan mangrove sehingga pertumbuhan pada semai menjadi lambat. Supardjo (2008) dan Usman et al. (2013) menambahkan kurangnya pasokan matahari dalam membantu proses fotosintesis terhalang oleh tingginya tegakan pohon dalam suatu kawasan mangrove sehingga semai tidak tumbuh dengan baik.

\subsection{Indek nilai penting mangrove}

INP menggambarkan jumlah kehadiran jenis mangrove di setiap plot pengamatan yang menunjukkan penyebaran dan keberadaan tiap jenis mangrove. Prasetyo et al. (2014) dan Kepel et al. (2017) juga menambahkan bahwa semakin besar nilai INP maka semakin besar pula peranan atau nilai ekologis dari suatu komunitas mangrove. INP tingkat pohon berkisar antara 63,5-300 (Gambar 9). Jenis E. agallocha memiliki nilai INP tertinggi pada stasiun I. Tingginya nilai INP E. agallocha menandakan bahwa spesies ini dominan dan mampu beradaptasi dengan baik pada kondisi lingkungan di Desa Sebubus Kabupaten Sambas. INP tertinggi mangrove C. tagal ditemukan di stasiun II sebesar 234,9 ind/Ha dan terendah ditemukan di stasiun III (44,21 ind/Ha). Mangrove $B$. gymnoryza ditemukan di stasiun III dengan nilai INP tertinggi (146,36
ind/Ha) dan di stasiun IV dengan INP terendah yaitu 63,5 ind/Ha. Rendahnya mangrove $B$. gymnoryza dikarenakan substrat yang tidak cocok bagi pertumbuhan jenis ini, dimana pada stasiun IV lebih besar persentase kandungan lanau dibandingkan pasir dan lempung. Akbar et al. (2016) juga menyatakan bahwa B. gymnoryza sangat sulit ditemukan pada daerah substrat berlumpur. Mangrove tingkat tiang didapatkan INP kisaran 47,75-300 ind/Ha (Gambar 10). Jenis E. agallocha memiliki nilai INP tertinggi pada stasiun I yang mewakili area dekat pemukiman yaitu sebesar $300 \mathrm{ind} / \mathrm{Ha}$. Tingginya nilai INP $E$. agallocha menandakan bahwa spesies ini dominan dan mampu beradaptasi dengan baik pada kondisi lingkungan di Desa Sebubus Kabupaten Sambas. Selain itu, E. agallocha merupakan tumbuhan mangrove minor, umumnya tumbuh pada arah daratan, dan jauh dari fluktuasi genangan pasang-surut (Setyawan et al., 2008).

Mangrove tingkat pancang hanya ditemukan 1 jenis pada masing-masing stasiun pengamatan. E. agallocha ditemukan di stasiun I dengan INP 200 ind/Ha. Mangrove C. tagal hanya ditemukan di stasiun II dengan INP 200 ind/Ha. Sedangkan $R$. mucronata, INP tertinggi

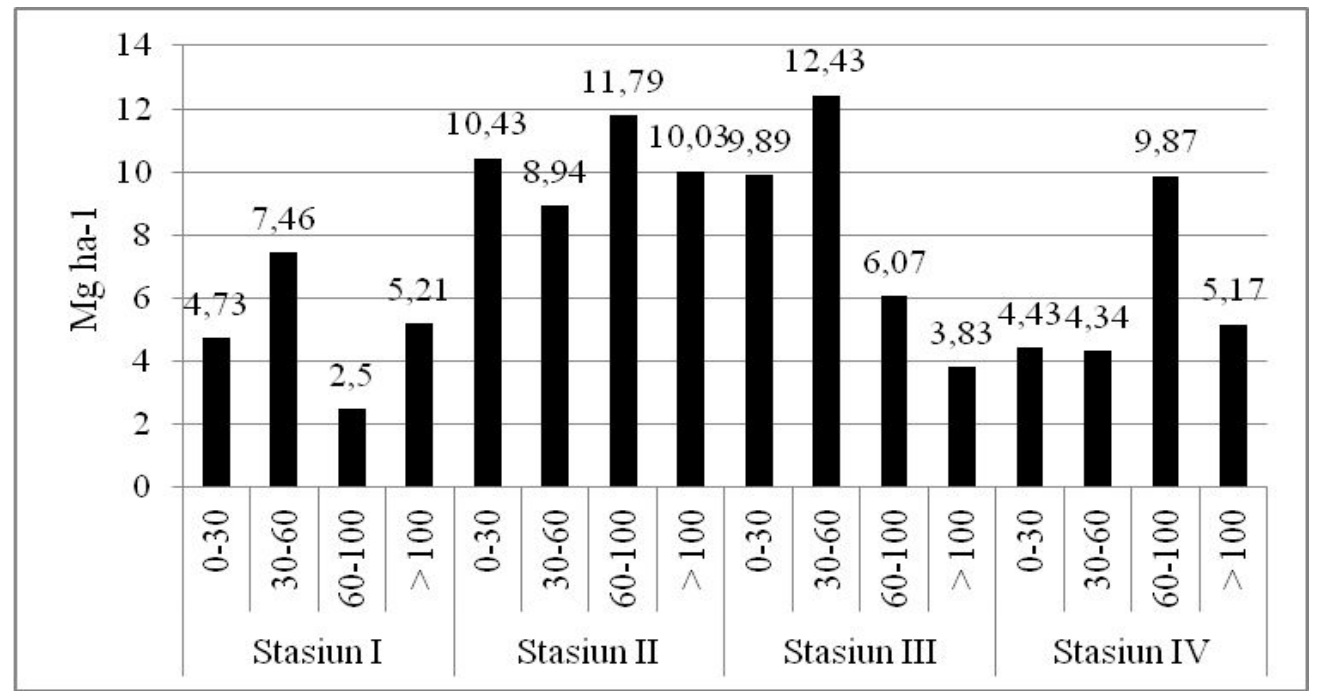

Gambar 11. Estimasi karbon pada setiap stasiun pengamatan 
Tabel 2. Nilai parameter lingkungan

\begin{tabular}{|c|c|c|c|c|c|c|}
\hline \multirow{2}{*}{ Parameter } & \multicolumn{4}{|c|}{ Stasiun pengamatan } & \multirow{2}{*}{$\begin{array}{c}\text { Rentang } \\
\text { optimal }\end{array}$} & \multirow{2}{*}{ Keterangan } \\
\hline & I & II & III & IV & & \\
\hline $\begin{array}{l}\text { Salinitas } \\
(\mathrm{ppt})\end{array}$ & 21,40 & 25,07 & 24,90 & 25,10 & $\begin{array}{l}\text { 2- } 38 \\
\text { (Hilmi, } \\
\text { 2005) }\end{array}$ & $\begin{array}{c}\text { Berperan dalam } \\
\text { menentukan sebaran } \\
\text { mangrove (Kordi, 2012) }\end{array}$ \\
\hline $\begin{array}{l}\text { Suhu } \\
\text { perairan } \\
\left({ }^{\circ} \mathrm{C}\right)\end{array}$ & 28,47 & 28,03 & 27,83 & 28,47 & $\begin{array}{c}28-32 \\
\text { (KLH No } 51 \\
\text { tahun 2004) }\end{array}$ & $\begin{array}{c}\text { Mempengaruhi } \\
\text { pertumbuhan mangrove } \\
\text { dan aktivitas } \\
\text { metabolisme (Kordi, } \\
\text { 2012) }\end{array}$ \\
\hline $\begin{array}{l}\text { Suhu tanah } \\
\quad\left({ }^{\circ} \mathrm{C}\right)\end{array}$ & 28 & 28 & 27 & 29 & - & $\begin{array}{c}\text { Faktor lingkngan yang } \\
\text { menentukan } \\
\text { pertumbuhan mangrove } \\
\text { dan aktivitas } \\
\text { metabolisme (Kordi, } \\
\text { 2012) }\end{array}$ \\
\hline $\mathrm{pH}$ perairan & 6,51 & 6,13 & 6,14 & 6,17 & $\begin{array}{l}\text { 7-8,5 } \\
\text { (KLH No } 51 \\
\text { tahun 2004) }\end{array}$ & $\begin{array}{c}\text { Berperan dalam } \\
\text { pertumbuhan mangrove } \\
\text { dan nutrisi dalam kawasa } \\
\text { mangrove (Hutasoit et } \\
\text { al., 2017) }\end{array}$ \\
\hline $\mathrm{pH}$ tanah & 6,33 & 5 & 4,83 & 6,50 & - & $\begin{array}{c}\text { Berperan dalam } \\
\text { pertumbuhan mangrove } \\
\text { dan nutrisi dalam kawasa } \\
\text { mangrove (Hutasoit et } \\
\text { al., 2017) }\end{array}$ \\
\hline $\mathrm{DO} \mathrm{mg} / \mathrm{L}$ & 6,57 & 5,67 & 5,37 & 5,53 & $\begin{array}{l}\quad>5 \\
(\text { KLH No } 51 \\
\text { tahun 2004) }\end{array}$ & $\begin{array}{c}\text { Membentuk zonasi } \\
\text { mangrove (Prasetyo, } \\
\text { 2014) }\end{array}$ \\
\hline
\end{tabular}

ditemukan di stasiun III (200 ind/Ha) dan terendah ditemukan di stasiun IV (200 ind/Ha). Nilai INP yang tinggi dapat menggambarkan bahwa jenis mangrove tersebut mampu bersaing dengan komunitas lainnya dan disebut jenis dominan (Renta et al., 2016), sehingga dapat dikatakan jika setiap jenis mangrove tingkatan pancang yang ditemukan pada setiap stasiun berpengaruh dalam satu komunitas. Permadi (2016) menjelaskan bahwa terjadinya perbedaan nilai penting vegetasi mangrove dikarenakan adanya kompetisi pada setiap jenis untuk mendapatkan unsur hara dan sinar cahaya matahari.

\subsection{Keanekaragaman jenis mangrove}

Keanekaragaman merupakan indeks yang digunakan untuk menentukan tingkat keanekaragaman suatu jenis dan sekaligus menjadi ukuran dalam menilai proses suksesi yang berjalan dalam komunitas (Tulenan et al., 2018). Kondisi seimbang di ekosistem mangrove akan ditemukan tingkat keanekaragaman yang tinggi.

Indeks keanekaragaman jenis di Desa Sebubus Kabupaten Sambas pada tingkatan pohon, tiang, pancang dan semai termasuk dalam kategori rendah yaitu berkisar antara 0-0,9596. Keanekaragaman jenis suatu komunitas bergantung pada jumlah jenis dan banyaknya individu pada suatu jenis yang ditemukan (Akbar et al., 2017 dan Tulenan et al., 2018). Indriyanto (2006) dan Irpan et al. (2017) juga menambahkan tingkat keanekaragaman jenis suatu komunitas dikatakan tinggi apabila komunitas hutan itu disusun oleh banyak jenis, dan suatu komunitas dikatakan rendah jika komunitas hutan disusun oleh sedikit jenis. Keanekaragaman jenis mangrove tertinggi untuk semua tingkatan terdapat di stasiun I pada tingkat pohon yang mewakili area jauh dari aktivitas manusia yaitu sebesar 0,9596 . 
Tabel 3. Tekstur tanah

\begin{tabular}{|c|c|c|c|c|c|}
\hline $\begin{array}{c}\text { Stasiun } \\
\text { pengamatan }\end{array}$ & $\begin{array}{c}\text { Lempung } \\
(\%)\end{array}$ & $\begin{array}{c}\text { Pasir } \\
(\%)\end{array}$ & $\begin{array}{l}\text { Lumpur } \\
(\%)\end{array}$ & Jenis substrat & Keterangan \\
\hline Stasin I & 13 & 47 & 40 & Lempung & Berperan \\
\hline Stasiun II & 18 & 29 & 53 & Lumpur lempung & dalam \\
\hline Stasiun III & 18 & 30 & 52 & Lumpur lempung & regenerasi \\
\hline Stasiun IV & 19 & 29 & 52 & Lumpur lempung & $\begin{array}{l}\text { tumbuhan } \\
\text { mangrove }\end{array}$ \\
\hline
\end{tabular}

Rendahnya keanekaragaman jenis mangrove menandakan ekosistem pada lokasi tersebut mengalami tekanan atau kondisi lingkungan yang menurun dan berubah (Adi, 2013 dan Tefarani et al., 2019). Menurunnya kondisi lingkungan mangrove di Desa Sebubus diduga karena semakin meningkatnya aktivitas antropogenik dan pemanfaatan lahan untuk kegiatan budidaya perikanan.

\subsection{Karbon pad sedimen mangrove}

Hasil pengukuran karbon sedimen pada kawasan mangrove Desa Sebubus Kabupaten Sambas Kalimantan Barat berdasarkan kedalaman diperoleh nilai kandungan karbon yang berbeda (Gambar 11). Kandungan karbon organik sedimen tertinggi terdapat pada stasiun III (12,43 MgC Ha-1), tingginya kandungan karbon sedimen dipengaruhi oleh jenis sedimen. Ati et al. (2014) menambahkan bahwa sedimen dengan persentase lumpur yang tinggi pada umumnya kaya bahan organik. Menurut Mahasani et al. (2016) akar tumbuhan mangrove diduga berperan dalam menyumbangkan kandungan karbon organik dalam sedimen.

Berdasarkan olah data yang telah dilakukan pada empat stasiun pengamatan menunjukan bahwa persentase karbon tertinggi yaitu pada kedalaman $0-30 \mathrm{~cm}$ dan $60-100 \mathrm{~cm}$ sedangkan nilai persentase terendah pada setiap stasiun berada pada kedalaman $>100 \mathrm{~cm}$. Donato et al. (2012) menemukan bahwa karbon organik sedimen banyak tersimpan di atas profil tanah, sedangkan pada kedalaman $>100 \mathrm{~cm}$ kandungan karbon organik sedimen menurun.

Perbedaan nilai persentase kandungan karbon organik pada setiap stasiun juga dipengaruhi oleh tingkat kerapatan dan keanekaragaman jenis mangrove yang berbeda pada masing-masing stasiun. Rusaknya lahan mangrove akibat pembukaan lahan memberikan dampak pada kandungan karbon organik (Kepel et al., 2018).

\subsection{Parameter lingkungan}

Kondisi parameter lingkungan di kawasan mangrove Desa Sebubus Kabupaten Sambas Kalimantan Barat seperti substrat, salinitas, suhu, $\mathrm{pH}, \mathrm{DO}$ dapat di lihat pada Tabel 1 dan 2. Parameter lingkungan yang optimal menjadi faktor pertumbuhan yang mendukung kehidupan jenis mangrove. Menurut Oktavianti (2017), apabila kondisi lingkungan berubah maka makhuk hidup akan menyesuaikan diri terhadap kondisi yang baru, berupa perubahan tingkah laku maupun morfologi. Berdasarkan Keputusan Kementerian Lingkungan Hidup No 51 Tahun 2004 kondisi lingkungan di Desa Sebubus Kabupaten Sambas masih dalam rentang baik bagi pertumbuhan mangrove. Hasil pengukuran tekstur tanah mangrove di Desa Sebubus Kabupaten Sambas menunjukkan bahwa kandungan tekstur lumpur mempunyai nilai persentase tertinggi, diikuti dengan banyaknya tekstur lempung, dan pasir. Keadaan substrat yang umumnya berjenis lempung sangat cocok untuk pertumbuhan anakan Rhizophora (Masithah et al., 2016).

\section{Kesimpulan}

1. Komposisi jenis mangrove di Desa Sebubus Kabupaten Sambas ditemukan 5 jenis mangrove yaitu E. agallocha, B. gymnoryza, C. tagal, S. alba dan R. mucronata. Keanekaragaman pada kawasan hutan mangrove tersebut masuk dalam kategori rendah dan tingkat kerapatan mangrove masuk dalam kategori jarang.

2. Estimasi karbon organik pada kawasan hutan mangrove di Desa Sebubus Kabupaten Sambas berkisar antara 2,5-12,43 Mg Ha-1. Kandungan karbon sedimen tertinggi ditemukan pada 
kedalaman $0-60 \mathrm{~cm}$ dan terendah pada kedalaman $>100 \mathrm{~cm}$.

\section{Ucapan Terima Kasih}

Penulis mengucapkan terimakasih kepada orangtua, seluruh dosen dan mahasiswa Ilmu Kelautan angkatan 2015 yang telah membantu dalam penyelesaian penelitian ini.

\section{Daftar Pustaka}

Adi, J. S., 2013, Komposisi jenis dan pola penyebaran gastropoda hutan mangrove blok Bedul Segoro Anak Taman Nasional Alas Purwo Banyuwangi, Jurnal Ilmu Dasar, 14(2):99-110

Ati, R. N. A.; Rustam, A.; Kepel, T. L.; Sudirman, N.; Astrid, M.; Daulat, A.; Mangindaan, P.; Salim, H. L.; Hutahean, A. A., 2014, Stok Karbon dan Struktur Komunitas mnagrove Sebagai Blue Karbon Di Tanjung Lesung Banten, Badan Pusat Penelitian dan Pengembangan Kelautan dan Perikanan-KKP, Jakarta Utara

Akbar, N.; Baksir, A.; dan Tahir. I., 2015, Struktur Komunitas ekosistem mangrove di kawasan pesisir Sidangoli Kabupaten Halmahera Barat, Maluku Utara, J. Depik, 4(3):132-143

Barbier, E. B.; Hacker, S. D.; Kennedy, C.; Koch, E.W.; Stier, A.C.; and Silliman, B. R., 2011, The value of estuarine and coastal ecosystem services. J.Ecological Monographs, 81, 169-19

Donato, D. C., Kauffman, J. B. Mudiyarso, D., Kurnianto, S., Stidham, M., dan Kanninen, M., 2011, Mangrove Among the Most Carbon-rich Forest in the Tropics. J. Nature Geosciense, 4(5): 293-297

Habdiansyah, P.; Lovadi, I.; dan Linda, R.; 2015, Profil Vegetasi Mangrove Desa Sebubus Kecamatan Paloh Kabupaten Sambas, J. Protobiont, 4(2) : 9-17

Indriyanto, 2006, Ekologi Hutan, Bumi Aksara, Jakarta.

Irpan, B.F.; Manurung, F,T.; dan Muflihati., 2017, Komposisi Dan Struktur Vegetasi Penyusun Zonasi Hutan Mangrove Tanjung Prapat Muda-Tanjung Bakau Kabupaten Kubu Raya, J.Hutan Lestari, 5 (1) : 104 - 112

Kepel, T.L.; Suryono, D.D.; Ati, R.N.; Salim, H.L.; dan Hutahaean, A.A., 2017, Nilai Penting dan Estimasi Nilai Ekonomi Simpanan Karbon Vegetasi Mangrove di Kema, Sulawesi Utara, J.Kelautan Nasional, 12(1):19-26

Mahasani, I. A.; Widagti, N.; Karang, A. G., 2015, Estimasi Presentase Karbon Organik Di Hutan Mangrove Bekas Tambak Perancak Jembrana Bali, J. Marine and aquatic sciences, $1: 14-18$

Masithah, D.; Kustanti, A.; dan Hilmanto, R., 2016, Nilai ekonomi komoditi hutan mangrove di desa Merak Belantung Kecamatan Kalianda Kabupaten Lampung Selatan, J. Sylva Lestari, 4(1):69-80

Murdiyarso, D.; Mackenzie, R..; and Kauffman, B.J., 2014. Approaches to Use Coastal MarineEcosystems for Climate Change Mitigation.

Oktavianti, R.; Nurdin, J.; dan Herwina, H., 2018, Komunitas Collembola pada hutan konservasi dan perkebunan sawit di kawasan PT. Tidar Kerinci Agung (TKA), Sumatera Barat, J. Biologi UNAND, 5(1):16-24

Setyawan, A. D.; Winarno, K.; Indrowuryatno.; Wiryanto.; Susilowati, A., 2008, Tumbuhan Mangrove di Pesisir Jawa Tengah: 3. Diagram Profil Vegetasi, J. Biodiversitas, 9(4) : 315-321

Sondak, C. F. A., 2015, Estimasi Potensi Penyerapan Karbon Biru (Blue Carbon) Oleh Hutan Mangrove Sulawesi Utara, J. Of Asean Studies On Maritime Issues, 1:1

Standar Nasional Indonesaia., 2004, Air dan Limbah, Bagian. 14 Cara uji Oksigen Terlarut Secara Yodometri. Badan Standarisasi Nasional.

Supriharyono, 2017, Konservasi Ekosistem Sumber Daya Hayati di Wilayah Pesisir dan Laut Tropis, Pustaka Pelajar, Yogyakarta.

Tefarani, R.; Martuti, T. K. N.; dan Ngabekti, S., 2019, Keanekaragaman Spesies Mangrove dan Zonasi di Wilayah Kelurahan Mangunharjo Kecamatan Tugu Kota Semarang, J.Biologi, 8(1):41-53

Tulenan, M. M.; Wantasen, A. S.; dan Rember, u., 2018, Struktur Komunitas Mangrove Di Pesisir Pantai Desa Palaes Kecamatan Likupang Barat Kabupaten Minahasa Utara, J. ilmuah platax, 6:1 